\title{
Conscious Decision to Engage in Defensive Silence: An Expectancy Theory Perspective
}

\author{
Dr. AMEN IMRAN \\ Lecturer: Institute of Management Studies, University of Peshawar. \\ Email: Amen_wasai@hotmail.com \\ Dr. SUNDUS WASAI KHAN \\ Lecturer: Department of Management Sciences, \\ Shaheed Benazir Bhutto Women University, Peshawar. \\ Email: sunduswasai@gmail.com \\ Mr. SAMIULLAH KHAN \\ Research Analyst, Tax Policy Unit- KPRA, Peshawar. \\ Email: sammiullah1@ hotmail.com
}

\begin{abstract}
The supervisor's negative attitude towards voice and unavailability of communication channels are considered significant predictors of defensive silence. However, lesser consideration has been given to provide an in-depth explanation of how and why these motivational forces influence employees' step by step conscious decision to engage in defensive silence. This qualitative study incorporates semi-structured interviews with bank employees of Khyber Pakhtunkhwa, Pakistan. Thematic coding and causal networking techniques were used to transcribe and analyse data and derive emerging themes. Taking influence from the elements of Expectancy Theory, this paper extends theory in the context of service sector by presenting two expectancy theory based defensive silence models. The first model provides reasons such as favoritism, political appointment, supervisor's self-interest etc., to explain how and why the supervisor's negative attitude towards voice influences employees' cognitive mechanism to adopt defensive silence. Similarly, the second model presents the emerging themes like centralized decision system, career ladder, leg pulling, professional jealousy etc., to explain how and why unavailability of communication channels predicts defensive silence. Thus, the study extends the application of expectancy theory and defensive silence phenomenon to new empirical context. The paper concludes with a discussion on implications and recommendations for future work.
\end{abstract}

Keywords: Defensive Silence; Supervisor's Negative Attitude Towards Voice; Unavailability of Communication Channels.

\section{Introduction}

Since employee input is one of the main sources of gaining competitive advantage, a significant and active involvement of employees is necessary for the better performance of the organization (Jiang, Le \& Gollan, 2017; Morrison, 2014; Mowbray, 2017). The success of the firm is rigorously weakened unless employees willingly deliver quality input, hence firms motivate their employees to raise voice. However, based on some self-desired outcomes, employees intentionally remain silent (Vakola \& Badorus, 2005). This intentionality to engage in silence behavior is described as defensive silence, which is a conscious decision of an employee, based on desired outcome to protect oneself from the risk of negative consequences (Khalid \& Ahmed, 2015; Pilař, Pokorná, \& Balcarová, 2014). 
According to Prouska and Psychogios (2016) voice and silence are not just the presence or absence of freedom of expression; instead the key insight that differentiate silence and voice is one's motivation behind the behavior of withholding or sharing relevant information, opinions and concerns about firm issues.

A lot of past researches reveals that a variety of work focused on the different ways in which employees are motivated to speak up at work such as issue selling, whistle-blowing, championing, dissent, and boatrocking, employee safety calculus etc. (Dutton \& Ashford, 1993; Hatipoglu \& IneImen, 2017; Miceli \& Near, 1992; Mowbray, 2017; Withey \& Cooper, 1989). Each of these streams of research, in one way or another, helps us to understand the motives that can encourage an employee to inform organizational decision makers about problems, strategic issues, new ideas, and ethical breaches. But these efforts have generally not considered the unique nature or implications of defensive silence neither shed light on the understanding the motivational forces that motivates employees to intentionally remain silent about the organizational issues (Jiang et al., 2017; McNulty, McPhail, Inversi, Dundon \& Nechanska, 2018).

Literature on employee motivation to intentionally remain silent (defensive silence) have suggested that the decision to choose silence rather than voice behavior as a response to voice opportunity is a conscious decision and stems more from motivational forces in the organization (Khalid \& Ahmed, 2015; Prouska \& Psychogios, 2016). Morrison and Millken (2000) highlighted supervisor's negative attitude towards voice and unavailability of communication channels to be the significant motivational forces which significantly leads to defensive silence. However very few studies have empirically analyzed that how these motivational forces influence employees' step by step conscious decision to engage in defensive silence.

Applying motivation theories and models to the process of employees' decision making to choose defensive silence has not commonly been done. (McConville, Arnold \& Smith, 2018), presented that expectancy theory can provide suitable theoretical framework for research to investigate individual motivation to perform in varied working context. Additionally, expectancy theory has been acknowledged as one of the most promising conceptualizations of individual motivation (Redmond, 2014). The theory proposed that an individual selects the behavior and the level of effort that he exert, based on his subjective estimation of the expectancy that the selected behavior will lead to desired outcomes (Wei, Piaw, Kannan, \& Moulod, 2016).

Therefore, primary purpose of this study is to incorporates the expectancy theory with the domain of employee silence to get deeper understanding of how the elements of expectancy theory, i.e. expectancy, instrumentality and valence, determine the step by step cognitive decision making process of engaging in defensive silence and how motivational forces (like supervisor's negative attitude towards voice and unavailability of communication channels) influence this decision process.

\section{Research Aim}

The overall aim of this research is to generate an in-depth understanding of how the determinants of employee silence influence employees' cognitive decision making process to choose defensive silence using the elements of expectancy theory.

\section{Research Question}

This study aims to answer the following question through empirical investigation:

- RQ1: How and why certain motivational forces such as supervisor's negative attitude towards openness and unavailability of communication channels influence employees' step by step conscious decision to engage in defensive silence, through expectancy theory? 


\section{Review of Literature}

Employee silence is described as withholding of important ideas, suggestions and information (Holland, Cooper \& Hecker, 2016; Morrison, 2014; Wilkinson, Gollan, Kalfa \& Xu, 2018). There are three main types of employee silences based on certain underlying motives. Acquiescent silence, refers to silence because of resignation motive, however Prosocial silence is based on cooperation motive, whereas Defensive silence is defined as silence based on fear motive (Khalid \& Ahmed, 2015; Pinder \& Harlos, 2001).

The focus of this study is on the particular type of silence i.e. defensive silence which takes place as a response to a desire of avoiding the risk of facing negative outcomes It is evident from the literature that defensive silence is intentional in nature. Based on the influence of certain motivational forces that are existing in the work setting, and due to the desire outcome of avoiding negative consequences, employees deliberately opt for silence as a safe communicative behaviour (Prouska \& Psychogios, 2016).

Furthermore, Defensive silence is considered as pre-emptive behavior (Dyne, Ang, \& Botero, 2003). While taking a decision to remain silent, an individual is well aware of the alternative behaviors and after analyzing the cost and benefits associated with each alternative, takes a conscious decision to opt for silence as the safest response (Pinder \& Harlos, 2001).

\section{Motivational Forces Behind Defensive Silence}

In today's competitive world of business, service industry such banks are in a dire need of creativity and innovation to expand its competitive edge over competitors. However, employees feel hesitation to share creative ideas and suggestions to achieve organizational goals more effectively and efficiently (Jiang et al., 2017). This in return leads to low level of commitment, reduced motivation, poor job performance etc. (Morrison \& Milliken, 2000). In such work setting, certain organizational factors, such as supervisor's positive attitude towards voice and availability of communication channels, act as motivational forces and can encourage the employees to speak up their voice (Holland et al., 2016; Mowbray, 2017; Rees, Alfes, \& Gatenby, 2013). Likewise, it is suggested that to deal with the fear and insecurity of employees, supportive supervisor who encourage employees' participation and involvement; and open communication opportunity are needed; or organization will face downfall in profitability and poor performance (Alparslan, Can, \& Erdem, 2015; Hatipoglu \& IneImen, 2017). Yet, most of the firms ignores these above mentioned motivational forces which than leads to supervisor's negative attitude towards voice and unavailability of communication channels and result in heavy cost to the business.

Supervisor's negative attitude towards voice is described as incompetency of the supervisor to promote voice behavior (Detert \& Edmondson, 2011). It acts as a motivational force behind defensive silence and motivate employees to deliberately hold on relevant information to avoid the risk of facing negative consequences (Rees et al., 2013). Whereas, unavailability of communication channels refers to as inability to freely exchange ideas and information with the top management and colleagues ( $\mathrm{Lu} \& \mathrm{Xie}, 2013$ ). In support of this argument, it is reported that these motivational forces motivate employees to opt for defensive silence as a safe response, but in return the organization faces heavy financial loss $(\mathrm{Ng}$. \& Feldman, 2012).

Moreover, Morrison and Milliken (2000) found that due to the existence of aforementioned organizational factors employees perceive the context to be unfavorable and not dare to raise voice. Further, to avoid the risk of facing negative outcomes they deliberately remain silent even if they have creative ideas and suggestions regarding organizational development (Holland et al., 2016; Morrison, 2014; Mowbray, 2017). 


\section{Conscious Decision to Engage in Defensive Silence: Expectancy Theory Perspective}

The aforementioned studies found that supervisor's negative attitude towards voice and unavailability of communication channels negatively influence employees' decision to raise voice and employees intentionally adopt defensive silence, due to the risk of negative consequences (Detert \& Edmondson, 2011; Hatipoglu \& IneImen, 2017; Morrison, 2011; Pacheco et al., 2015). However, these researches lack to empirically elaborate how and why these motivational forces impacts step by step conscious decision making process to engage in defensive silence (Milliken, Morrison, \& Hewlin, 2003; Wilkinson et al., 2018). Applying Expectancy Theory of Motivation and Process (Vroom, 1964) to the concept of employee silence answer this theoretical gap (Lunenburg, 2011).

According to Vroom (1964) there are three components of Expectancy Theory i.e. expectancy, instrumentality and valence. These components when joins together forms the motivational force to engage in a particular behavior out of available alternatives. Expectancy refers to one's belief that exerted effort leads towards desired performance. If efforts do not result in desired performance than expectancy is low and an individual is not motivated to adopt that behavior (Lunenburg, 2011). However, instrumentality is described as an individual perception that if performance expectations are met, the desired outcome will be achieved. If it is said to be no relationship between performance and expected outcome, then instrumentality is low and individual is less motivated to engage in that behavior (Mercer, Carpenter, \& Wyman, 2010).

Whereas, valence measures the extent to which an individual values the outcome. This value could be -1 which means negative valence, hence individual tries to avoid the outcome; 0 value which indicates an indifferent attitude towards the outcome; or +1 which refers to positive valence and an individual prefers the outcome (Hellriegel \& Slocum, 2011; McShane \& Von Glinow, 2011). When these components are combined, it forms the Motivational Force to adopt a particular behavior amongst the available alternatives (Greenberg, 2011; Redmond, 2014). If there is low level of expectancy and instrumentality followed by negative or zero valence, Motivational Force also becomes zero. Hence, a particular behavior is not adopted (McConville et al., 2018; Vroom, 1964).

Expectancy Theory model treats individual as an active agent who rationally takes a decision to opt for any alternative behavior based on the environmental scanning to predict the influence of the existing motivational forcers as well as the desired outcomes (Fred, 2011; Wei et. al., 2016). It also provides an indepth and step by step explanation of one's cognitive decision (McConville et al., 2018; Parijat \& Bagga, 2014). Furthermore, it is stated that the selection of an alternative behavior is based on expectancy that the selected behavior will help to achieve the probable satisfaction and the desired output. Similarly, Redmond (2014) mentioned that the selected alternative behavior is the outcome of one's attitudes, perceptions and beliefs about maximizing gains and minimizing losses, which ultimately determine one's motivation, actions, choices and performance in different working environment.

\section{Steps by Step Decision Towards Defensive Silence}

Based on the literature on Expectancy Theory, the following three steps are conceptualized to indicate the cognitive mechanism involved while taking a decision to engage in defensive silence.

\section{Existence of Voice Opportunity}

Most of the time employees have voice opportunity that is a situation when they have something important to share but they must make a wise decision either to raise voice or to remain silent (Pacheco, de Serpa Arruda, \& Caldeira, 2015). This decision is based on the influence of certain motivational forces present in the working environment and their desired outcome (i.e. to avoid the risk of facing negative consequences) (Dyne et al., 2003). 


\section{Environmental Scanning}

To judge the favorability of the context, individual scan the environment to against the prevailing motivational forces (Detert \& Trevino, 2010; Grant, 2013). When these motivational forces ensure favorable context, employees feel safe to speak up and raise their voice (McNulty et al., 2018). Whereas under unfavorable context these motivational forces motivate employees to engage in defensive silence to avoid the risk of negative outcomes (Moore, Hester, \& Yager, 2016).

\section{Desired Outcome}

Besides the influence of the motivational forces prevailing in the environment, the desired outcome also influences ones' decision to either raise voice or to remain silent (Hassan, Bano, Shaukat, \& Nawaz, 2013; Pinder \& Harlos, 2001). It is stated that the desired outcome to protect oneself from the risk of facing negative consequences influences one's decision to deliberately engage in defensive silence behavior (Dyne et al., 2003; Pilař et al., 2014).

This relationship is shown in fig. 1 below.

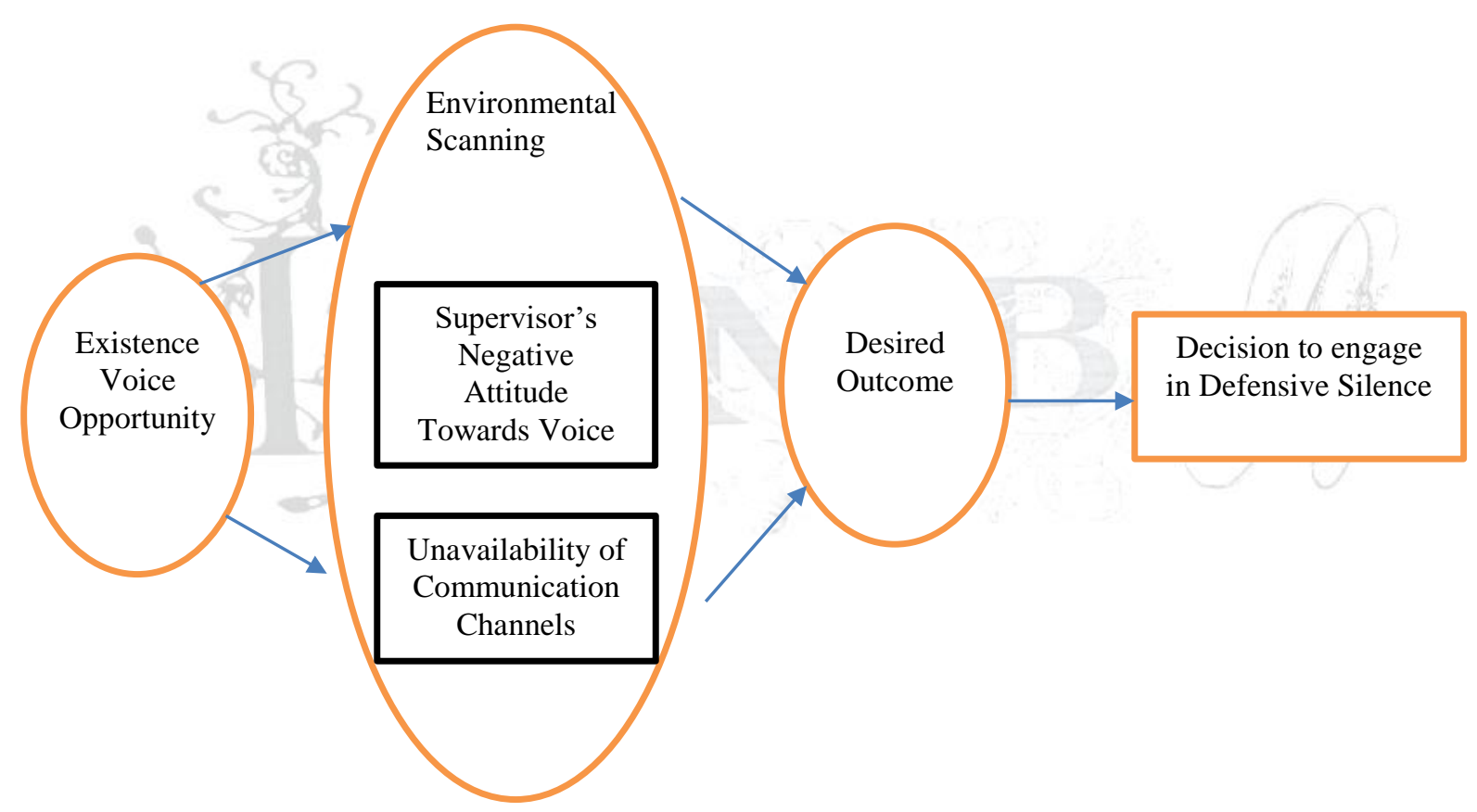

Figure 1: Conceptualization of Steps by Step Defensive Silence

\section{Expectancy Theory-Based Defensive Silence Model}

By synergizing the Expectancy Theory with the employee silence phenomenon, helps to understand the conscious decision process. It further facilitates to explain how the components of Expectancy Theory i.e. expectancy, instrumentality and valence forms a Motivational Force to propel and employee to exert his efforts and to engage in silence behavior (Vroom, 1964). These components further help to elaborate the step by step conscious decision process to engage in defensive silence, based on the influence of certain motivation forces and the desired outcomes (McConville et al., 2018). 
Based on the above literature on Defensive Silence and Expectancy Theory it is extracted that when there is unfavorable environment which promotes supervisor's negative attitude towards voice and unavailability of communication channels (Imran \& Nouman, 2017), employees perceive that the supervisor will discourage their voice behavior and will not listen to their problems (Detert \& Edmondson, 2011; Prouska \& Psychogios, 2016; Rees et al., 2013). Furthermore, employees perceive management to be reluctant towards free flow of information sharing with the top management and colleagues (Cakici, 2010), (high expectancy). Under such circumstances, employees' probability of facing negative consequences increases (high instrumentality).

Moreover, the desired outcome of an employee is to avoid the risk of facing negative consequences. Hence, under unfavorable conditions employee perceives it futile to raise voice (negative valence). This ultimately results in low Motivational Force to speak up and therefore he takes a rational decision to choose defensive silence as a safe behavior (Prouska \& Psychogios, 2016).

\section{Hypothesis and Conceptual Framework}

Based on the above discussion, following hypothesis and conceptual framework are derived.

H1: Supervisor's negative attitude towards voice impacts decision to choose defensive silence, through the elements of expectancy theory.

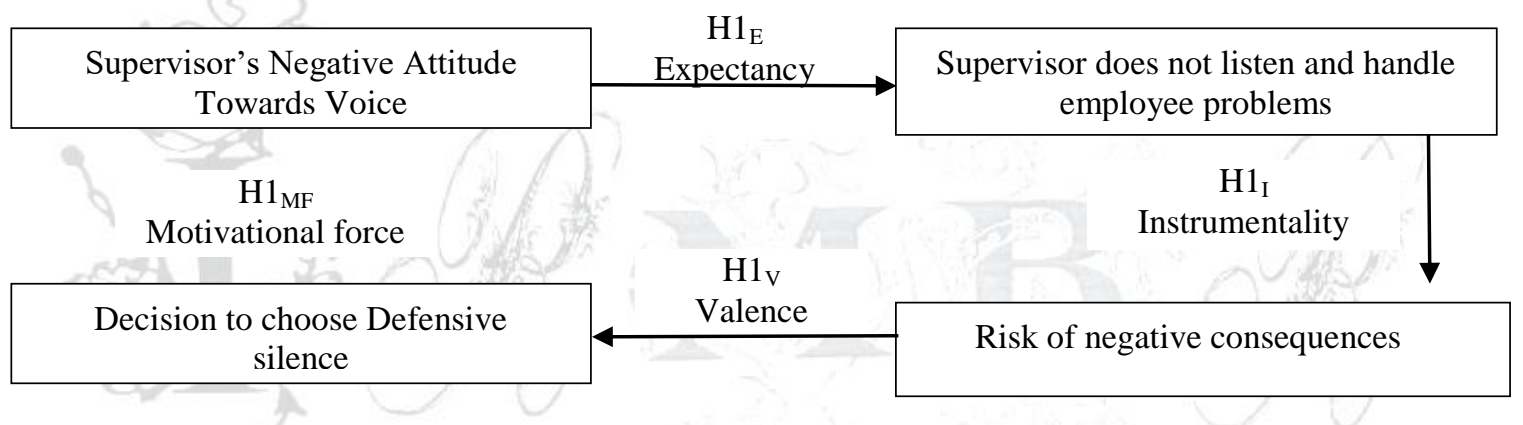

Figure 2: Conceptual Framework: Supervisor's Negative Attitude Towards Voice Impacts Decision to Choose Defensive Silence, Through Elements of Expectancy Theory

H2: Unavailability of communication channels impacts decision to choose defensive silence, through the elements of expectancy theory.

\begin{tabular}{|c|c|c|}
\hline $\begin{array}{c}\text { Unavailability of Communication } \\
\text { Channels }\end{array}$ & $\begin{array}{c}\mathrm{H} 2_{\mathrm{E}} \\
\text { Expectancy }\end{array}$ & $\begin{array}{c}\text { Organization discourage availability of } \\
\text { open communication channel to openly and } \\
\text { fairly exchange information with top }\end{array}$ \\
\cline { 3 - 3 } $\begin{array}{c}\mathrm{H} 2_{\mathrm{MF}} \\
\text { Motivational force }\end{array}$ & $\begin{array}{c}\mathrm{H} 2_{\mathrm{I}} \\
\text { Instrumentality }\end{array}$ \\
\hline $\begin{array}{c}\text { Decision to choose Defensive } \\
\text { silence }\end{array}$ & Ralence & Risk of negative consequences \\
\hline
\end{tabular}

Figure 3: Conceptual Framework: Unavailability of Communication Channels Impacts Decision to Choose Defensive Silence, Through Elements of Expectancy Theory 


\section{Research Methodology}

Due to the high pressure of globalization, Pakistan's banking sector is facing highly competitive and stressful environment. These circumstances create many job-related issues for the employees but they hesitate to speak up about these issues due to the fear and risk of confronting negative results, hence they indulge in defensive silence. Therefore, this condition makes it more conducive to study how and why certain motivational forces such as supervisor's negative attitude and unavailability of communication channel influence step by step conscious decision to engage defensive silence behaviour in the banking context.

This study was conducted in banking sector of Khyber Pakhtunkhwa (KP). There are 26 commercial banks (out of which 5 were public and 21 were private) in 25 districts of KP. A sample of 8 banks, based on substantial branch network, and 12 districts of KP, based on population density were selected. The two motivational forces i.e. supervisor's negative attitude towards voice and unavailability of communication channel were considered as the independent variables whereas defensive silence was considered as dependent variable.

\section{Data Collection}

Semi structured interview was used for data collection. 2 interviewees from each district were selected through stratified purposive sampling. The interview guide was developed based on three steps (Gilbert, 2008). The first step was determining the framework of the interview guide. Second, clearly identifying the themes that will be used to analyze the interview feedback and lastly developing the list of questions to asked during the interview. To ensure the reliability and validity of the interview guide, it was reviewed by the experts in the field and necessary changes were made as per their advice (see Appendix A). Moreover, to analyze the data collected and to develop themes based on the transcribed data thematic coding technique was used (see Appendix B). Whereas causal networking technique was used for the visual presentation of the analyzed data and to develop the expectancy theory based defensive silence model.

\section{Data Analysis and Results}

\section{Relationship Between Supervisor's Negative Attitude to Voice and Defensive Silence}

The feedback of the informants helped to generate new themes to get an in-depth explanation of as to how and why supervisor's negative attitude towards voice leads to defensive silence in banks. The themes are discussed as under:

\section{Misuse of Authority}

The feedback of the informants highlighted that in most of the branch manager is the sole authority. He is empowered by the head office to take decision regarding employees' roles, responsibilities and job rotation. In this case, he doesn't encourage more ideas and innovations by the employees rather impose his decision. This environment signals risk of negative outcomes and employees are forced to remain silent.

\section{Subjective Appraisal System}

Informants mentioned that their performance appraisal is in the hand of branch manager. He is responsible for evaluating and appraising the performance of all employees, which is mostly done based on good relation with the manager. Under such circumstances they are forced to accept work overload, work from home, extra working hours etc. informants reported that due to the fear of negative performance appraisal they can never say no to their manager even for the extra work burden and hence remain silent. 


\section{Favoritism}

The feedback of the informants highlighted the fact that branch manager doesn't treat all employees equally rather favoritism is encouraged. Those who have some family terms or have good relation with the manager are given preference in terms of fringe benefit, half day, more sick leaves, training and development, less job rotation and promotion opportunity etc. This situation increase the risk of facing negative outcomes and employees perceive it risky to speak up.

\section{Political Appointment}

During the interview, most of the informants revels the fact that most of the job appointments are done based on political influence rather than competency. The incompetent individuals are hired due to political pressure. These political appointees not only pressurize managers for extra benefits but also discourage competent employees to work hard and attain higher targets. This unfavorable context propels other employees to remain silent even if they have innovative ideas and suggestion for better work performance.

\section{Supervisor's Self-Interest Decision}

While sharing the personal experiences, informants expose the reality that while voucher postings, sometimes mistakes may happen. It is the responsibility of the branch manager to counter check all work and is liable to ask employees to rectify mistakes if any, before sending it to higher ups. Due to negligence if wrong voucher posting is reported to the head office, instead of accepting his mistake, branch manager take disciplinary action against the employee and report it to Head office.

\section{High Insecurity}

Informants reported that due to the branch manager's negative attitude, their feeling of insecurity is very high, for if they raise voice about their issues of work overload, job monotonous, stressful work setting etc., they will be considered as lazy and incompetent by the manager. Hence, they perceive defensive silence as a safe communicative behavior under such conditions.

\section{Supervisor's Incompetency}

Based on the informants' responses, it was discovered that when managers feel incompetent in their skills and expertise, they discourage ideas and suggestions by the employees regarding work simplification techniques and adoption of new technology. When branch managers lack certain skills to cope with new technology, he criticizes employees to apply advance technological work practices. In return employees feel no point to share their ideas and creativity and remain silent.

The Expectancy Theory based Defensive Silence Model in relation to supervisor's negative attitude towards voice presents the new emerging themes to explains the association between the study variables. Whereas the elements of Expectancy Theory are discussed below to provide an in-depth explanation of how and why supervisor's negative attitude leads to defensive silence in the banking context.

Expectancy: Due to the prevailing Supervisor's negative attitude, employees perceive that if voice is raised, it may result in misuse of authority by the supervisor, poor performance appraisal, favoritism, political appointment, supervisor's self-interest decisions, high insecurity and discouragement of innovative ideas due to supervisor incompetency.

Instrumentality: if supervisor apply the above emerging themes, there will be a high risk of facing negative consequences in terms of poor performance evaluation and disciplinary action. 
Valence: Employees discourage that behavior which may increase the risk of negative consequences.

Motivational Force: hence, employees are motivated to take a conscious decision to engage in defensive silence as a safe communicative behavior.

The above themes are presented below in the model in fig. 4 .

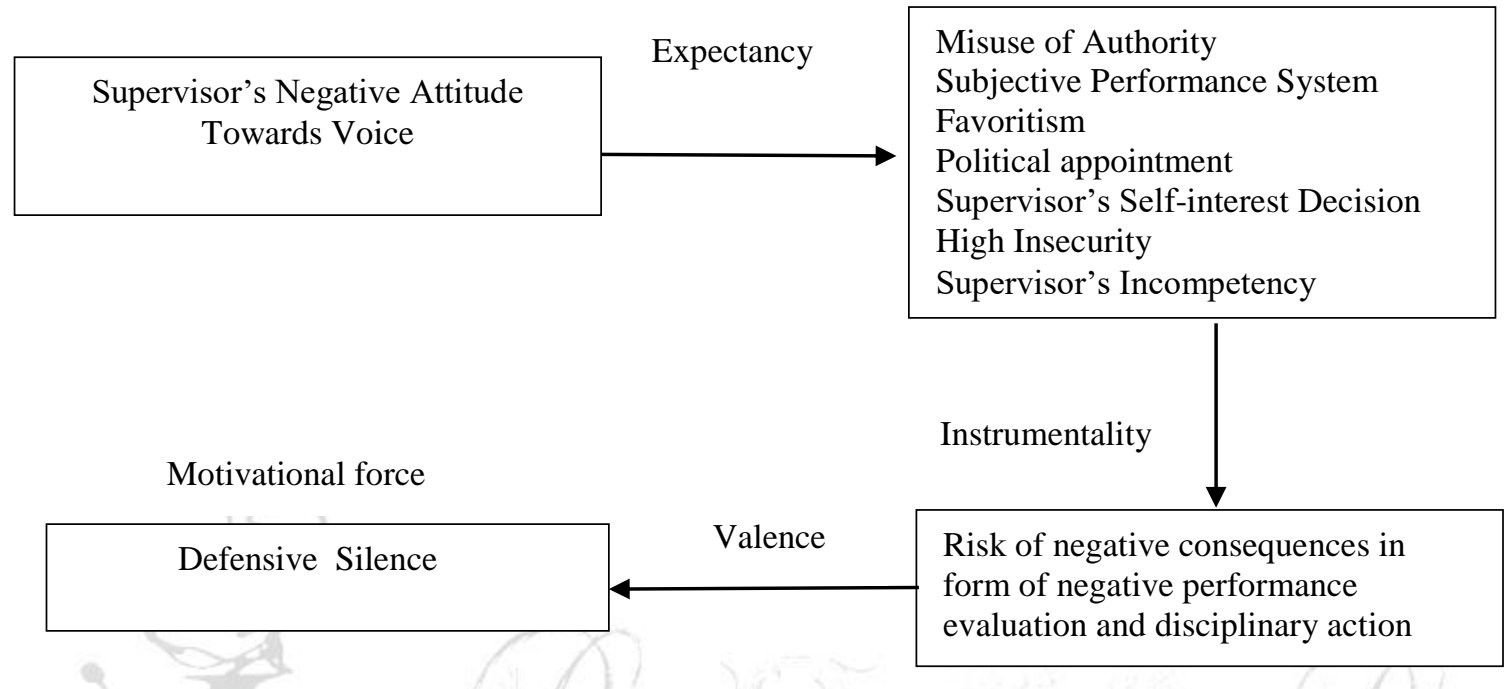

Figure No. 4, Expectancy Theory- Based Defensive Silence Model: in Relation to Supervisor's Negative Attitude Towards Voice

\section{Relationship Between Unavailability of Communication Channels and Defensive Silence}

Based on the informants' feedback following new emerging themes were derived to explain the association between unavailability of communication channels and defensive silence.

\section{Centralization}

In was revealed from the informants' feedback that while taking a decision, the branch manager only listen to their ideas and suggestions but never incorporate them and take a sole decision that suits him. Moreover, the banking system is composed of centralized decision system. The decisions are imposed by the head office without any prior notification or consultation. In such circumstances employees get no opportunity to raise voice.

\section{Career Ladder}

The informants discussed that there is a very slow career path in the banking system. Promotions are not based on the competencies and there is no performance appreciation by either branch or head office. There is no communication opportunity to discuss their good performance with the top management, as they only rely on branch manager's feedback about performance evaluation. Hence, employees remain silent.

\section{Leg Pulling}

During the interview, most of the informants mentioned that due to lack of open communication channels there is leg pulling by the colleagues and often by the branch manager as well. Mostly the co-workers use 
informal communication channels to covey negative feedback about other colleagues with the top management who have personal relation with them. Hence, to avoid the risk of facing negative consequences, employees remain silent and low profile.

\section{Professional Jealousy}

Informants mentioned that due to the centralized communication system, the good performers are not recognized by the top management, as head office only rely on branch manager feedback. On the other hand, the incompetent branch manager and seniors develop professional jealousy and discourage good performers for their hard efforts. In such unfavorable context, the hardworking employees get demotivated and don't want to face any negative outcomes by going against the seniors or branch manager. Hence, they engage in defensive silence.

\section{Reduced Level of Trust}

Informants reported that they feel uncomfortable while discussing their job-related issues with other colleagues and branch manager due to lack of trust. They feel that if they discuss their matters they will be perceived as trouble maker and lazy by the branch manager and top management. Hence, they feel it as a safe response to remain silent and to avoid the risk of negative outcomes.

\section{Poor Recognition and Reward}

The feedback of information make it evident that banking system of KP, Pakistan lacks performance based reward and appreciation system. Informants mentioned that they are not given rewards and mostly managers get the bonuses and higher rewards. Only managers are appreciated and certified for the target achievements rather than the whole team. This leads to high level of demotivation and employees prefer to remain silent than to raise voice.

The above new emerging themes are shown in the model below in fig. 5 .

Unavailability of Communication Channels
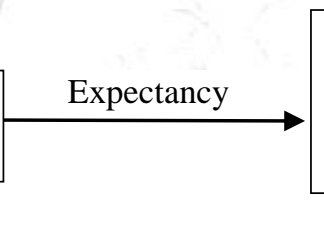

Centralized Decision System Career Ladder

Leg pulling

Professional jealousy

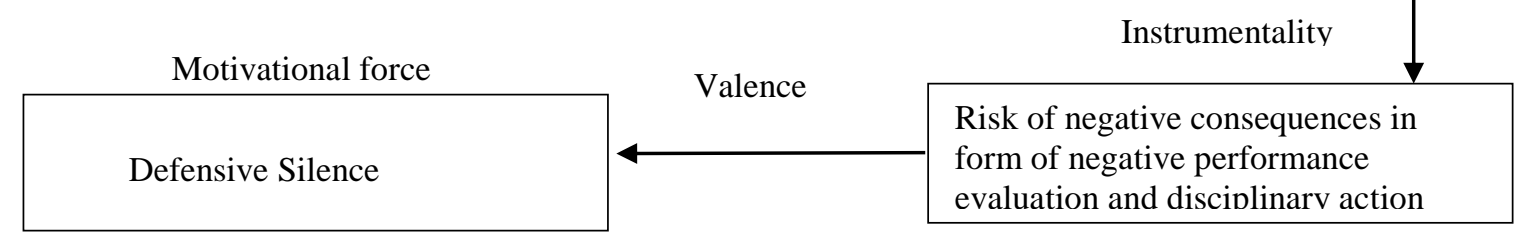

Figure No. 5, Expectancy Theory- Based Defensive Silence Model: in Relation to Unavailability of Communication Channel.

This model represents, centralization, career ladder, leg pulling, professional jealousy and reduced level of trust as the key themes to explain how and why unavailability of communication channel influence ones' step by step conscious decision to engage in defensive silence, in the banking sector of KP Pakistan. The above model, with the help of the elements of Expectancy Theory is discussed as follows. 
Expectancy: When there is unavailability of communication channel, employees perceive that if voice is raised it might not create a difference due to the centralized decision system, weak career path, leg pulling by colleagues, professional jealousy and lack of trust.

Instrumentality: Under the prevalence of aforementioned practices, employees perceive high risk of facing negative outcomes in terms of negative performance evaluation or disciplinary action.

Valence: Employees does not engage in such behavior that raise the risk of negative consequences.

Motivational Force: Hence, Employees take a conscious decision to engage in defensive silence behavior as a safe response.

\section{Discussion}

This study aimed at investigating the association between the motivational forces (supervisor's negative attitude towards voice and unavailability of communication channels) and defensive silence, through the elements of Expectancy Theory. To get an in-depth explanation for how and why supervisor's negative attitude and unavailability of communication channels act as a motivational force behind ones' conscious decision to engage in defensive silence this study was conducted in the banking sector of Khyber Pakhtunkhwa (KP). Semi structure interview was conducted to collect data. Based on the data collected, this paper develops the Expectancy Theory- based defensive silence models for the banking sector of KP, Pakistan.

Moreover, this study synergizes the concept of defensive silence with Expectancy theory and with the help of the elements of Expectancy theory i.e. expectancy, instrumentality and valence give an in-depth explanation of the step by step conscious decision making process to engage in defensive silence. It further helps to explain the reasons for how and why such relationship exist among the study variables (Dyne et al., 2003; Morrison, 2014; Prouska \& Psychogios, 2016).

Based on the informants' feedback following new emerging themes were drawn to explain the reason for how and why supervisor's negative attitude influence step by step conscious decision to engage in defensive silence, particularly in the banking sector of KP, Pakistan. These themes are: misuse of authority, subjective performance system, favouritism, political appointment, self-interest decision by manager, high insecurity, and incompetency of leader.

Moreover, the findings of the study further reveal the reasons for how and why unavailability of communication channels influence ones' cognitive decision process to opt for defensive silence as a safe response. These themes are: centralization, career ladder, leg pulling, professional jealousy and reduced trust level.

\section{Conclusion}

These resulting models of the study identified the new emerging themes which help the researchers, practitioners and academicians to develop new strategies in overcoming defensive silence. It further helps to understand what are the motivational forces organizations should avoid in their efforts to encourage employee voice behaviour. Based on the findings of the study provides sound theoretical contributions for the HR managers, banks management and the policy makers to give more attention to supervisor positive attitude towards voice and to provide open communication channels to allow free flow for exchange of information up the hierarchy. Similarly, the results of the study promote further research in the same filed by exploring the new emerging themes to understand the relationship among the study variables. 


\section{Research Implications}

This study not only contributes to the expansion of employee silence phenomenon but also provides theoretical contribution by extending the application of Expectancy Theory in the field of employee silence particularly with respect to banking sector of KP, Pakistan. This theoretical stance provides new avenues to the policy maker and practitioners in terms of strategy development and their implication. The study concludes that the service industry like banks should support employee voice behaviour by provision of free flow of information through open communication channels and supervisor's positive attitude towards voice. In the prevalence of these motivational forces employees perceived risk of facing negative consequence will decrease and they will speak up about issues and problems and will feel free to provide suggestions and ideas for problem solving and innovation. This is the only way to gain competitive advantage in today's world of business.

\section{Limitations and Recommendations for Future Research}

Besides empirically testing the effect of supervisor's negative attitude towards voice and unavailability of communication channels, other motivational forces like grapevine, personality types, cross cultural differences etc. could be considered as defensive silence motives. Moreover, some other factors could be added to the existing theoretical framework as the consequences of defensive silence such as job satisfaction, anxiety, job stress, depression, conflict among employees etc. These limitations present avenue for the future research and may allow further extension of the expectancy theory based defensive silence model.

\section{References}

Alparslan, A. M., Can, A., \& Erdem, R. (2015). Reasons for Employee Silence Behavior: Developing and Validating a Scale for Nurses. Hacettepe Sağllk Idaresi Dergisi, 18(2).

Çakıc1, A. (2010). The Silence of Employee in Organizations. Ankara: Detay Press.

Creswell, J. W. (2003). Research design: Quantitative, Qualitative, and Mixed Methods Approaches (2nd ed.). Thousand Oaks, CA: Sage.

Creswell, J. W., \& Clark, V. P. (2011). Designing and Conducting Mixed Methods Research (2nd ed.). Thousand Oaks, CA: Sage.

Detert, J. R., \& Edmondson, A. C. (2011). Implicit Voice Theories: Taken-for-granted Rules of SelfCensorship at Work. Academy of Management Journal, 54, 461-488.

Detert, J. R., \& Treviño, L. K. (2010). Speaking Up to Higher-ups: How Supervisors and Skip-level Leaders Influence Employee Voice. Organization Science, 21(1), 249-270.

Dutton, J. E., Ashford, S., Lawrence, K., \& Miner-Rubino, K. (2002). Red Light, Green Light: Making Sense of the Organizational Context for Issue selling. Organization Science, 13, 355-369.

Dyne, L. V., Ang, S., \& Botero, I. C. (2003). Conceptualizing Employee Silence and Employee Voice as Multidimensional Constructs. Journal of Management Studies, 40(6), 1359-1392.

Fred, C. L. (2011). Expectancy Theory of Motivation: Motivating by Altering Expectations. International Journal of Management, Business and Administration, 15(1), 1-6.

Gilbert, N. (2008). Researching Social Life. $3^{\text {rd }}$ ed. Sage Publications Ltd, London 2008. ISBN: 9781412946629.

Grant, A. M. (2013). Rocking The Boat But Keeping it Steady: The Role of Emotion Regulation in Employee Voice. Academy of Management Journal, 56(6), 1703-1723.

Greenberg, J. (2011). Behavior in Organizations (10th ed.). Upper Saddle River, NJ: Prentice Hall.

Hassan, M. U., Bano, T., Shaukat, S., \& Nawaz, M. S. (2013). Antecedents of Organizational Commitment: A Case of Banking Sector of Pakistan. World Applied Sciences Journal, 24(12), 1621-1628.

Hatipoglu, B., \& IneImen, K. (2017). Demographic Diversity in Workplace and its Impact on Employee Voice: The role of Trust in the Employer. The International Journal of Human Resource Management, 29(5), 970-994. doi:10.1080/09585192.2017.1322120. 
Hellriegel, D., \& Slocum, J. W. (2011). Organizational Behavior (13th ed.). Mason, OH: South-Western Cengage Learning.

Holland, P., Cooper, B. K., \& Hecker, R. (2016). Use of social media at work: a new form of employee voice? The International Journal of Human Resource Management, 27(21), 2621-2634. doi:10.1080/09585192.2016.1227867.

Imran, A., \& Nouman, M., (2017). Mediated Model of Defensive Silence: An Empirical Case of the Banking Sector in Khyber Pakhtunkhwa, Pakistan. Abasyn Journal of Social Sciences, 10(1), 178-191.

Jiang, Z., Le, H., \& Gollan, P. J. (2017). Cultural intelligence and voice behavior among migrant workers: the mediating role of leader-member exchange. The International Journal of Human Resource Management, 29(5), 1082-1112. doi:10.1080/09585192.2017.1322119

Khalid, J., \& Ahmed, J. (2015). Perceived Organizational Politics and Employee Silence: Supervisor Trust as a Moderator. Journal of the Asia Pacific Economy, 21(2), 174-195. doi:10.1080/13547860.2015.1092279

Lu, J., \& Xie, X. (2013). Research on Employee Silence Behavior: A Review Based on Chinese Family Enterprise. Asian Social Science, 9(17), 47.

Lunenburg, F. C. (2011). Expectancy Theory of Motivation: Motivating by Altering Expectations. International Journal of Management, Business, and Administration, 15(1).

McConville, D., Arnold, J., \& Smith, A. (2018). What do People Think Employee Share Ownership Schemes do for Them? A Qualitative Study of Participants' Experiences in Three UK Share Schemes. The International Journal of Human Resource Management.

McNulty, Y., McPhail, R., Inversi, C., Dundon, T., \& Nechanska, E., (2017). Employee Voice Mechanisms for Lesbian, Gay, Bisexual and Transgender Expatriation: The Role of Employee-Resource Groups (ERGs) and Allies. The International Journal of Human Resource Management.

McShane, S. L., \& Von Glinow, M. A. (2011). Organizational Behavior (5th ed.). New York: McGrawHill.

Mercer, M. K., Carpenter, G., \& Wyman. (2010). Pay for Results: Aligning Executive Compensation with Business Performance. New York, NY: Wiley.

Miceli, M. P., \& Near, J. P. (1992). Blowing the Whistle: The Organizational and Legal Implications for Companies and Employees. New York: Lexington Bo.

Milliken, F. J., Morrison, E. W., \& Hewlin, P. F. (2003). An Exploratory Study of Employee Silence: Issues that Employees Don't Communicate Upward and Why. Journal of management studies, 40(6), 1453-1476.

Moore, J. E., Hester, A. J., \& Yager, S. E. (2016). Paving the Higher Road: The Role of Voice in the Retention of IT Workers. ACM SIGMIS Database, 47(1), 8-28.

Morrison, E. W. (2011). Employee Voice Behavior: Integration and Directions for Future Research. The Academy of Management Annals, 5(1).

Morrison, E. W. (2014). Employee voice and Silence. Annual Review of Organizational Psychology and Organizational Behavior, 1(1), 173-197.

Morrison, E. W., \& Milliken, F. J. (2000). Organizational silence: A Barrier to Change and Development in a Pluralistic World. Academy of Management Review, 25(4), 706-725.

Mowbray, P. K. (2017). Giving a voice to managers: forging the desire line through the creation of informal employee voice channels and productive resistance. The International Journal of Human Resource Management, 29(5), 941-969. doi:10.1080/09585192.2017.1396552

Ng., T. W., \& Feldman., D. C. (2012). Employee Voice Behavior: A Meta-analytic Test of the Conservation of Resources Framework. Journal of Organizational Behavior, 33(2), 216-234.

Pacheco, D. C., de Serpa Arruda, A. I. D., \& Caldeira, S. N. (2015). Silence in Organizations and Psychological Safety: A Literature Review. European Scientific Journal.

Parijat, P., \& Bagga, S. (2014). Victor Vroom's Expectancy Theory of Motivation-An Evaluation. International Research Journal of Business and Management, 7(9), 1-8.

Pilař, L., Pokorná, J., \& Balcarová, T. (2014). Pro-active Behaviour in Context of Team Climate. Acta Universitatis Agriculturae et Silviculturae Mendelianae Brunensis, 62(4), 685-695. 
Pinder, C. C., \& Harlos, K. P. (2001). Employee Silence: Quiescence and Acquiescence as Responses to Perceived Injustice. Research in Personnel and Human Resources Management, 20, 331-369.

Prouska, R., \& Psychogios, A. (2016). Do Not Say a Word! Conceptualizing Employee Silence in a Longterm Crisis Context. The International Journal of Human Resource Management. 29(5), 885-914. doi:10.1080/09585192.2016.1212913.

Redmond, B.F. (2014). Lecture on Expectancy Theory (Lesson 4). Personal Collection of B.F. Redmond, Penn State University, University Park, PA.

Rees, C., Alfes, K., \& Gatenby, M. (2013). Employee Voice and Engagement: Connections and Consequences. International Journal of Human Resource Management, 24(14), 27802798. doi:10.1080/09585192.2013.763843

Vakola, M., \& Bouradas, D. (2005). Antecedents and Consequences of Organisational Silence: An Empirical Investigation. Employee Relations, 27(5), 441-458.

Vroom, V. H. (1964). Work and Motivation. San Francisco, CA: Jossey-Bass.

Wei, L. M., Piaw, C. Y., Kannan, S., \& Moulod, S. A. (2016). Relationship Between Teacher ICT Competency and Teacher Acceptance and Use of School Management System (SMS). Malaysian Online Journal of Educational Technology, 4(4), 36-52.

Wilkinson, A., Gollan, P. J., Kalfa, S., \& Xu, Y., (2018). Voices unheard: Employee Voice in The New Century. The International Journal of Human Resource Management, 29(5), 711-724. doi:10.1080/09585192.2018.1427347

Withey, M. J., \& Cooper, W. H. (1989). Predicting Exit, Voice, Loyalty, and Neglect. Administrative Science Quarterly, 34, 521-539.

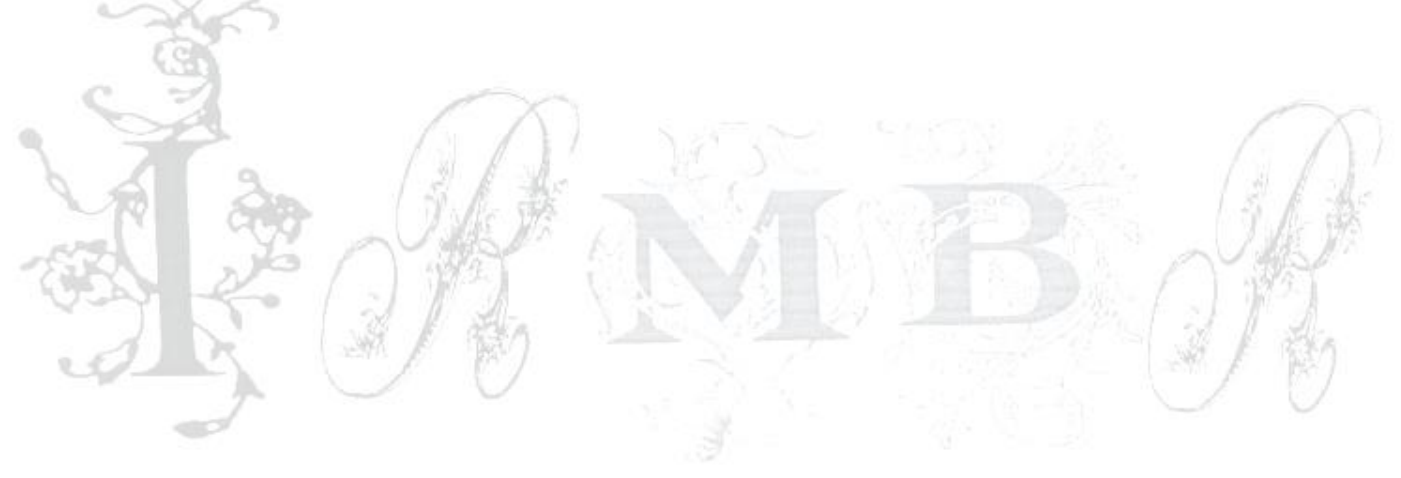




\section{Appendix A}

\section{Interview Questions}

- What are the reasons for Supervisor's negative attitude towards voice to be the predictor of defensive silence in the banks of KP Pakistan.

- What are the reasons for Unavailability of communication channels to be the predictor of defensive silence in the banks of KP Pakistan.

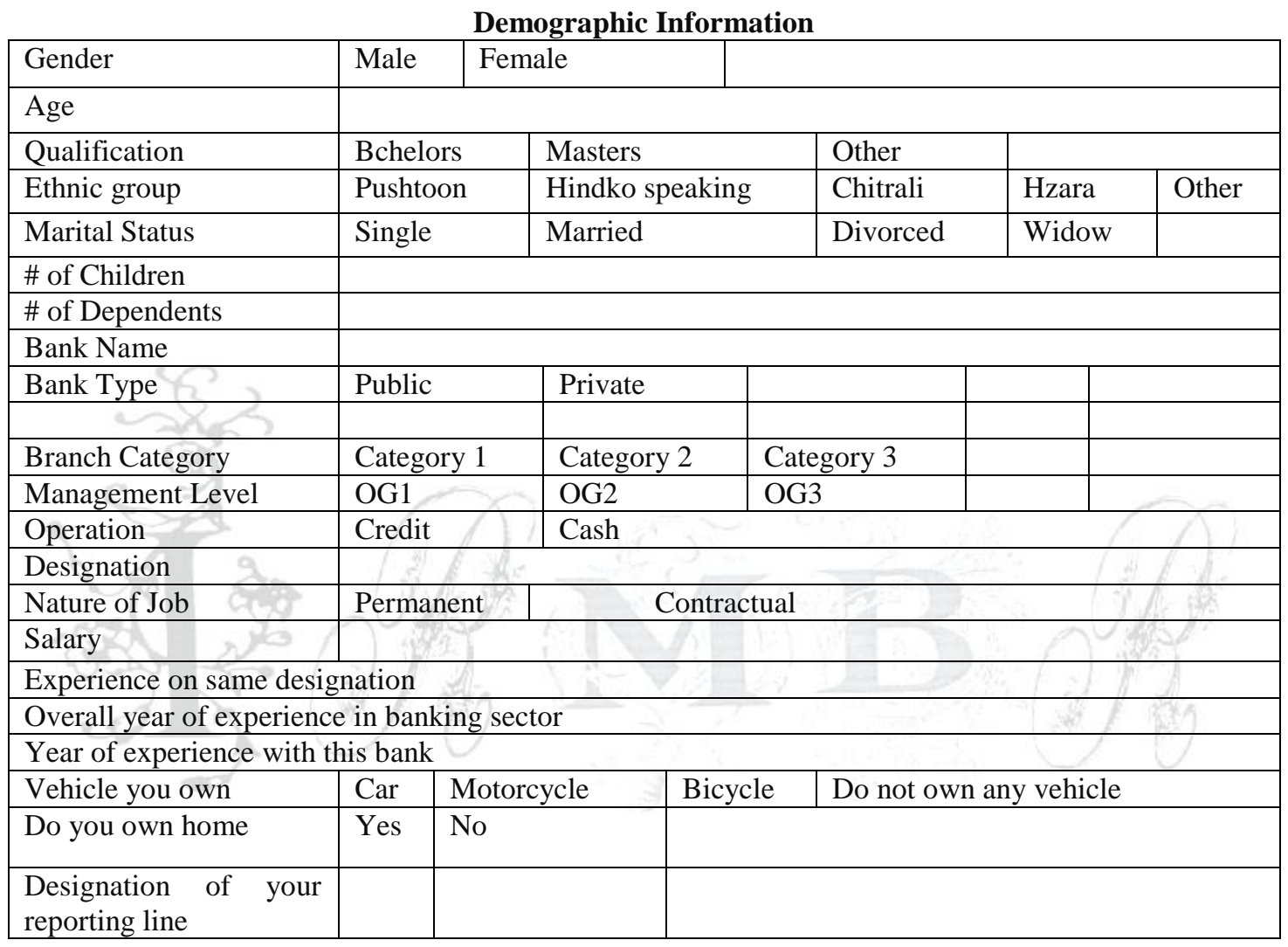

\begin{tabular}{|l|l|}
\hline Thank you for your time to complete this questionnaire! We appreciate your cooperation. \\
\hline Mobile \#of the respondent & \\
\hline Name of the researcher & \\
\hline Date of Survey & \\
\hline
\end{tabular}


Appendix B: Interview Coding (Sample)

\begin{tabular}{|c|c|c|c|c|c|}
\hline $\begin{array}{l}\text { Overarching } \\
\text { Themes/ } \\
\text { A priori codes/ } \\
\text { Pre- } \\
\text { determined } \\
\text { Themes }\end{array}$ & $\begin{array}{l}\text { Interpretive } \\
\text { Codes }\end{array}$ & Interviewees \# & Excerpt & $\begin{array}{c}\text { Inductive } \\
\text { sub-themes }\end{array}$ & $\begin{array}{l}\text { Descriptive } \\
\text { Codes }\end{array}$ \\
\hline \multirow[t]{4}{*}{$\begin{array}{l}\text { Motivational } \\
\text { Force }\end{array}$} & $\begin{array}{l}\text { Supervisor } \\
\text { negative } \\
\text { attitude } \\
\text { towards } \\
\text { voice }\end{array}$ & Int 1 & $\begin{array}{l}\text { In banks mostly managers don't } \\
\text { care about what his subordinates } \\
\text { are feeling. He takes decisions } \\
\text { on basis of his interest. He plays } \\
\text { safe game and don't want to } \\
\text { take any responsibility on his } \\
\text { shoulders. Only ALLAH can do } \\
\text { justice. }\end{array}$ & $\begin{array}{c}\text { Supervisor's } \\
\text { Self-interest } \\
\text { decision }\end{array}$ & MFLD-SI \\
\hline & & Int 2 & $\begin{array}{l}\text { Managers mostly do favouritism } \\
\text { with their friends and with those } \\
\text { people who are his relative or } \\
\text { belong to same village. Manager } \\
\text { gives them relaxment in work, } \\
\text { allow them for half day leave, } \\
\text { give them less responsibility etc. }\end{array}$ & Favouritism & MFLD-F \\
\hline & & Int 3 & $\begin{array}{l}\text { Our manager doesn't discuss our } \\
\text { appraisal with us and secretly } \\
\text { sent it to the top management } \\
\text { based on his observation. He do } \\
\text { subjective judgement. There is a } \\
\text { not objective criteria for } \\
\text { performance appraisal. }\end{array}$ & $\begin{array}{c}\text { Subjective } \\
\text { performance } \\
\text { system }\end{array}$ & MFLD-SPA \\
\hline & 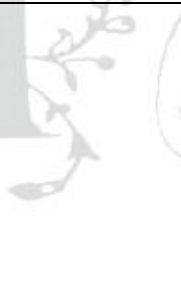 & Int 4 & $\begin{array}{l}\text { Our manager take decisions for } \\
\text { personal interest. During } \\
\text { decision making process he } \\
\text { listens for suggestions but don't } \\
\text { allow criticism. He use } \\
\text { autocratic style of leadership } \\
\text { and force us to do whatever he } \\
\text { want us to do. }\end{array}$ & $\begin{array}{l}\text { Misuse of } \\
\text { Authority }\end{array}$ & MFLD-MA \\
\hline \multirow[t]{2}{*}{$\begin{array}{l}\text { Motivational } \\
\text { force }\end{array}$} & $\begin{array}{c}\text { Unavailabilit } \\
\text { y of } \\
\text { Communicat } \\
\text { ion Channels }\end{array}$ & Int 13 & $\begin{array}{l}\text { In banks decisions are not } \\
\text { informed to us. We are not } \\
\text { involved in the decision making } \\
\text { process. Decisions are imposed } \\
\text { on us and we are not allowed to } \\
\text { disagree. We are forced to } \\
\text { follow otherwise we have to } \\
\text { face negative consequences. } \\
\text { Direct circular - no change is } \\
\text { informed beforehand. }\end{array}$ & $\begin{array}{l}\text { Centralizatio } \\
\mathrm{n}\end{array}$ & $\begin{array}{l}\text { MFCD- } \\
\text { CDM }\end{array}$ \\
\hline & Int19 & $\begin{array}{l}\text { In banks we } \\
\text { employees are not } \\
\text { given any reward } \\
\text { and appreciation. } \\
\text { Only managers get } \\
\text { reward and } \\
\text { bonuses and that's } \\
\text { why we feel } \\
\text { ignored. }\end{array}$ & Poor Recognition and Reward & MFCD-LA & Int19 \\
\hline
\end{tabular}

